Trakya Eğitim Dergisi

Cilt 9, Sayı 4

2019 Ek Sayı

Aralık 2019, 708-722

Geliş Tarihi: 31.01 .2019

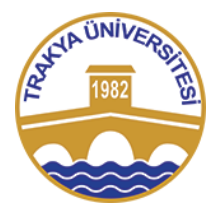

ISSN: 2630-6301
Trakya Journal of Education

Volume 9, Issue 4

2019 Additional Issue

December 2019, 708-722

Yayına Kabul Tarihi: 06.12.2019

DOI: $10.24315 /$ tred.520314

Araştırma Makalesi

\title{
Hayat Bilgisi Öğretim Programlarının Değerlendirilmesi (1926-2018)
}

\author{
Evalution of Life Science Curricula (1926-2018)
}

\author{
Selçuk ATÍK ${ }^{1}$, Necdet AYKAÇ
}

\begin{abstract}
Öz: Bu araştırmada, Cumhuriyetin kuruluşundan itibaren uygulanan 1926, 1936, 1948, 1968, 1998, 2005, 2009, 2015, 2017 ve 2018 Hayat Bilgisi dersi öğretim programlarının, eğitim programlarının ögelerini oluşturan hedef, içerik, öğrenme-öğretme süreci ve ölçmedeğerlendirme ögeleri esas alınarak değerlendirilmesi amaçlanmıştır. Araştırmada nitel araştırma yaklaşımı kullanılmıştır. Araştırma verileri, doküman incelemesi yöntemi ile elde edilmiş ve betimsel analiz ile çözümlenmiştir. Araştırmada elde edilen bulgulara göre; 1926, 1936, 1948 ve 1968 programlarında dönemin ihtiyaç ve beklentilerine göre genel hedeflerin belirlendiği görülmektedir. Hedeflerin ifadesinde 1998 programında davranışçı yaklaşım, 2005 ve sonrasındaki programlarda yapılandırmacı yaklaşım etkilidir. 1926, 1936, 1948 ve 1968 programlarında içerik yoğunken, 1998 ve sonraki programlarda içeriğin yoğunluğu kısmen azaltılmıştır. Öğrenme-öğretme sürecinde, 2005 öncesindeki programlarda öğretmen merkezli bir süreç egemenken, 2005 ve sonrasındaki programlarda, yapılandırmacı yaklaşımın etkisiyle öğrenci merkezli bir süreç gözlenmektedir. Ölçme-değerlendirme boyutunun 1998 programına kadar ihmal edildiği, 1998 ve sonraki programlarda ise daha fazla önem verildiği söylenebilir.
\end{abstract}

Anahtar sözcükler: Hayat bilgisi, ögretim programı, program değerlendirme

\begin{abstract}
The aim of this study is to evaluate the Life Science curricula used from 1926 to 2018, on the basis of the four basic elements of education programs. This is a qualitative research. The data were obtained by using document analysis and analyzed with descriptive analysis approach. According to the findings of the study; in pre-1998 programs, general objectives were determined according to the needs and expectations of the period. Behavioral approach in the 1998 program, and a constructivist approach in the 2005 and later programs are effective in the expression of objectives. While the content was intensive in pre-1998 programs, it was partially reduced in 1998 and later programs. While the learning-teaching process is teacher-centered in pre-2005 programs, a student-centered process is observed in 2005 and later programs. The measurement-evaluation has been neglected until the 1998 program, and that it is given more importance in 1998 and later programs.
\end{abstract}

Keywords: Life science, curriculum, curriculum evaluation

\section{Introduction}

\section{EXTENDED ABSTRACT}

In the first three classes of primary education, the Life Science course, which is at the center of teaching, enables the student to learn the events and facts starting from his / her close environment and to recognize the culture of the society in which he lives. For this reason, Life Science course is an important lesson for students who are new to primary education. In this course, the student examines the natural and social environment in which he / she is involved. Self-knowledge, to understand the environment and the events occurring in the environment, finding ways to live better, the location of the surrounding objects and how to use it is provided to know (Sahin, 2009).

With the declaration of the Republic, there was a need for innovations in the field of education. Education system of the Republic has been tried to be created. Some changes have been made to the programs implemented in schools in order to create the society that the newly established state needs and to train the human type. For this purpose, program development studies were started in 1924. In accordance with the expectations and needs of the period, the changes in the primary school programs were made in the following years and the Life Science curriculum was also affected by these changes.

The Life Science course took place in the 1926 primary school program for the first time and was taught as a pivot course in the first three classes of primary school since 1926. In the following years, 1936, 1948, 1968, 1998, 2005, 2009, 2015, 2017 and 2018 programs were prepared.

In this research, it was aimed to evaluate the Life Science curricula of 1926, 1936, 1948, 1968, 1998, 2005, 2009, 2015 and 2017, which have been implemented since the establishment of the

\footnotetext{
Öğretmen, Milli Eğitim Bakanlığı, Türkiye, s.atik48@hotmail.com, ORCID ID:0000-0002-3732-7803

Doç. Dr., Muğla Sitkı Koçman Üniversitesi, Eğitim Fakültesi, Eğitim Bilimleri Bölümü, Muğla - Türkiye, necdetaykac@hotmail.com, ORCID ID:0000-0001-8020-713X
} 
Republic, are based on the four basic elements of education programs: goals, content, learningteaching process and measurement-evaluation. For this purpose, it has been tried to examine the changes in the historical process in the context of goals, content, learning-teaching process and measurement-evaluation of Life Science curriculum. This study is important in order to evaluate the change in the Life Science curriculum with a holistic approach and to source future program development activities by taking the positive aspects of the past.

\section{Method}

Qualitative research approach was used in the research. The data of the research was obtained by using the document analysis of the data collection methods in qualitative research. 1926, 1936, 1948, 1968, 1998, 2005, 2009, 2015 and 2017 Life Science curricula accepted by the Ministry of National Education were used as the documents. The obtained data were analyzed with descriptive analysis approach and classified under goals, content, learning-teaching process and measurementevaluation dimensions.

\section{Result and Discussion}

According to the findings obtained in the research, it is seen that there are significant changes in the four dimensions of the programs. In the 1926, 1936, 1948 and 1968 programs, the general objectives of the Life Science course were determined according to the needs and expectations of the period. For the first time in the 1998 program, not only the general objectives of the course, but also the objectives and target behaviours belonging to the classes have been written. Behavioral approach in the 1998 program, and a constructivist approach in the 2005 and later programs are effective in the expression of objectives. Although there was intense content in the 1926, 1936, 1948, 1968 programs, the content intensity in the 1998 and later programs was partially reduced.

In the learning-teaching process, a teacher-centered process dominated the programs prior to 2005, and in 2005 and later programs, a student-centered process was observed with the effect of constructivist approach. In the 2005/2009 programs, the learning-teaching process is the most critical element of the program. Therefore, detailed explanations have been made about the process. The student-centered program is enriched with activities. In 2015, 2017 and 2018 programs, several explanations were made instead of detailed explanations regarding the implementation of the program. Activity examples have been removed.

It can be said that the measurement-evaluation dimension has been neglected until the 1998 program, and that it is given more importance in 1998 and later programs. In the 1998 program, the measurement and evaluation dimession was included for the first time. In the program, the conception of product evaluation is dominant. It is stated that observation form can be used with classical measurement and evaluation tools, teachers can prepare measurement question / observation form by using the table of specifications and can vary the measurement tools.In the programs prepared in 2005 and later, the conception of product and process evaluation was adopted with the effect of constructivist approach. In these programs, classical measurement and evaluation tools as well as alternative / multiple measurement and evaluation approaches have been used.

As a result, it is seen that significant changes have been made in the elements of Life Science education programs from 1926 until today. It can be said that the foundations of some changes which have been shown as new to our educational world by constructivist approach existed in the past programs. For this reason, while developing new programs with program development studies, having a cumulative point of view that combines past positive practices can provide more qualified and functional programs.

\section{GíRiş}

Temel eğitimin ilk üç sınıfında, öğretimin merkezinde olan Hayat Bilgisi dersi, öğrencinin, yakın çevresinden başlayarak olay ve olguları öğrenmesini, içinde yaşadığı toplumun kültürünü tanımasını sağlaması nedeniyle, ilköğretime yeni başlayan öğrenciler için önemli bir derstir. Hayat Bilgisi dersi; öğrencinin ruhunu dikkate alarak doğal ve toplumsal çevresiyle uyumunu sağlayan, yaparak yaşayarak öğrenme yoluyla öğrenciyi doğal yaşamla ilgili yararlı bilgilerle donatan, öğrenciyi hayata ve bir üst öğrenim basamağına hazırlayan, öğrenci merkezli, disiplinler arası bir derstir (Tay ve Yıldırım, 2013; Ocak ve Beydoğan, 2005). Bu dersle, çocuğun içinde bulunduğu doğal ve toplumsal çevreyi incelemesi, çevresinde meydana gelen olayları anlaması, çevresindeki eşyaların yerlerini ve bunları nasıl kullanacağını bilmesi, daha iyi yaşama yollarını bulması ve kendini tanıması sağlanır (Şahin, 2009).

Cumhuriyetin ilanından sonra, diğer alanlarda olduğu gibi, eğitim alanında da yeniliklerin yapılmasına ihtiyaç duyulmuştur. 1924 yılında çıkarılan Tevhid-i Tedrisat Kanunu (Öğretimin 
Birleştirilmesi) ile öğretim kurumlarının tamamı Milli Eğitim Bakanlığı'na bağlanmış ve Cumhuriyetin eğitim sistemi oluşturulmaya çalışılmıştır. Bununla birlikte, yeni kurulan devletin ihtiyaç duyduğu toplumu yaratmak ve insan tipini yetiştirmek için eğitim programlarında bazı değişiklikler yapılmıştır. Bu amaçla 1924 yılında program geliştirme çalışmalarına başlanmıştır. Dönemin beklentilerine ve ihtiyaçlarına uygun olarak ilerleyen yıllarda da ilkokul programlarında değişiklikler yapılmış ve Hayat Bilgisi öğretim programları da bu değişikliklerden etkilenmiştir.

Cumhuriyetin ilk programı olan 1924 İlk Mektepler Müfredat Programı'nda Hayat Bilgisi dersi yer almamakta; ancak o dönemde verilen Tarih, Coğrafya, Tabiat Tetkiki (Doğa İncelemesi), Ziraat, Hıfzıssıhha (Sağlık Bilgisi), Muhasabat-i Ahlakiye (Ahlak Sohbetleri) ve Malumat-i Vataniyye (Yurttaşlık Bilgisi) derslerinin kapsamı Hayat Bilgisi dersinin kapsamı ile oldukça benzerlik göstermektedir (Bıkmaz, 2013a). 1924 programının, geniş bir zamanda, verimliliği test edilmiş yeni bir müfredat hazırlanıncaya kadar kullanılması kabul edilmiştir. İki yıllık bir uygulamadan sonra, 1924 programı önemli ölçüde yenilenerek 1926 İlkmektepler Müfredat Programı yapılmıştır (Aslan, 2011). Bu müfredatta, 1924'te Türkiye'ye davet edilen John Dewey'in eğitim sistemimizle ilgili hazırladığı raporunda önemle bahsettiği "hayat bilgisi, toplu tedris ve iş okulu" kavramlarına yer verilmiştir (Şahin, 2009). "Toplu Tedris" ilkesi gereğince hayata dair pek çok konu ilk üç sınıf içerisinde (1-3.sınıflar) birleştirilmiş ve Hayat Bilgisi adı altında yeni bir ders, 1926 İlkmektepler Müfredat Programı'nda yer almıştır (B1kmaz, 2013b). Uygulanacak olan programlar ile yaşam arasında bağ kurulması gerektiğini belirten John Dewey'in görüşlerinin etkisiyle hazırlanan programlarda, Hayat Bilgisi dersi önemli bir yere sahip olmuş ve ilkokulun ilk üç sınıfinda mihver ders olarak kabul edilmiştir (Tay ve Baş, 2015).

1926 yılından itibaren ilkokulun ilk üç sınıfında mihver ders olarak okutulan Hayat Bilgisi dersi için dönemin beklenti ve ihtiyaçları doğrultusunda birtakım değişiklikler yapılarak, 1936, 1948, 1968, 1998, 2005, 2009, 2015, 2017 ve 2018 programları hazırlanmıştır. Zaman içerisinde programların ögelerinde yapılan değişikliklerle birlikte, dersin haftalık ders saatlerinde de değişiklik yapıldığı görülmektedir. Cumhuriyetin kuruluşundan itibaren uygulanan Hayat Bilgisi öğretim programlarındaki haftalık ders saatleri Tablo 1'de verilmiştir (Maarif Vekâleti [MV], 1930; Kültür Bakanlığı [KB], 1936; Milli Eğitim Bakanlığı [MEB], 1948, 1969; Vural, 2003, 2005; MEB, 2009, 2015, 2017, 2018).

Tablo 1. Programlara göre Hayat Bilgisi dersinin haftalık ders saatleri

\begin{tabular}{ccccc}
\hline Programlar & 1.Sinif & 2.Sinif & 3 . Sinif & Toplam \\
\hline 1926 & 4 & 4 & 4 & 12 \\
1936 & 5 & 6 & 7 & 18 \\
1948 & 5 & 6 & 7 & 18 \\
1968 & $200 \mathrm{dk}$ & $240 \mathrm{dk}$ & $240 \mathrm{dk}$ & $680 \mathrm{dk}$ \\
& $(60+60+40+40)$ & $(60+60+60+60)$ & $(60+60+60+60)$ & $(12)$ \\
1998 & 5 & 5 & 5 & 15 \\
$2005-2009$ & 5 & 5 & 5 & 15 \\
2015 & 4 & 4 & 3 & 11 \\
2017 & 4 & 4 & 3 & 11 \\
2018 & 4 & 4 & 3 & 11 \\
\hline
\end{tabular}

Tablo 1 incelendiğinde, Hayat Bilgisi dersi haftalık ders saatlerinin bazı programlarda değiştiği görülmektedir. 1926 programında haftada 12 ders iken, 1936 ve 1948 programlarında \%50 artışla haftada 18 derse çıkarılmıştır. 1968 programında esnek davranılarak, haftalık işlenmesi gereken zaman üzerinden ders cetveli hazırlanmıştır. Haftada 1.sınıflar için 200 dakika, 2. ve 3.sınıflar için 240 dakika Hayat Bilgisi dersi işlenmesine karar verilmiştir. Sonraki programlarda tekrar eski sisteme dönülmüş; 1998, 2005 ve 2009 programlarına haftada 15; 2015, 2017 ve 2018 programlarına haftada 11 saat Hayat Bilgisi dersi konulmuştur. Hayat Bilgisi dersinin haftalık ders saatlerinde son hazırlanan programlar ile birlikte \% 27 düşüş olduğu, haftalık ders saatlerinin azaldığı dikkati çekmektedir.

Hayat Bilgisi öğretim programı ile ilgili alanyazın incelendiğinde, Hayat Bilgisi öğretim programlarının değerlendirilmesi konusunda çalışmalar yapıldığı görülmektedir (Alak, 2011; Aykaç, 2011; Belet, 1999; Demir, 2016; Gümüş ve Aykaç, 2012; Güven, 2010; Özden, 2006; Öztürk ve Kalafatç1, 2017; Şahin, 2009; Şahin, 2017; Tay ve Baş, 2015; Uğur, 2006). Bu çalışmalar incelendiğinde programların değerlendirilmesinin daha çok öğretmen görüşlerine göre ya da belli programların karşılaştırılmasına yönelik olduğu görülmektedir. Bu araştırmada ise, Hayat Bilgisi öğretim programlarının hedef, içerik, öğrenme-öğretme süreci ve ölçme-değerlendirme boyutlarında, tarihsel süreç içerisinde uğradığı değişiklikler ele alınmaya çalışılmıştır. Yaşanan dönemin ihtiyaçlarına ve beklentilerine uygun olarak 
Hayat Bilgisi öğretim programlarının geçirdiği değişimi, bütüncül bir yaklaşımla değerlendirmek, geçmişin de olumlu yanlarını alarak, gelecekteki program geliştirme çalışmalarına kaynaklık etmek adına, bu çalışma önem arz etmektedir. Bu boyutuyla bakıldığında detaylı bir analiz ürünü olan araştırmanın, Hayat Bilgisi öğretim programları hakkında alanyazında yapılacak araştırmalara katkı sunabileceği düşünülmektedir. $\mathrm{Bu}$ bağlamda araştırmanın genel amacı, Cumhuriyetin kuruluşundan itibaren uygulanan 1926, 1936, 1948, 1968, 1998, 2005, 2009, 2015, 2017 ve 2018 Hayat Bilgisi öğretim programlarının, eğitim programlarının temel ögelerine göre değerlendirilmesidir. Bu amaçla Hayat Bilgisi öğretim programlarının,

- Hedef,

- İçerik,

- Öğrenme-öğretme süreci,

- Ölçme-değerlendirme ögeleri açısından geçirdiği değişikliklerin karşılaştırmalı olarak ele alınması amaçlanmıştır.

\section{YÖNTEM}

\subsection{Araştırmanın Modeli}

$\mathrm{Bu}$ araştırmada Hayat Bilgisi programlarını, program ögelerine göre değerlendirmek amacıyla nitel araştırma yaklaşımı kullanılmış, programlar karşılaştırmalı olarak program ögelerine göre betimlenmiştir. Nitel araştırma, sayısal olmayan kelime, resim, imge gibi nitel verilerin toplandığı ampirik bir araştırmadır (Christensen, Johnson ve Turner, 2015). Nitel araştırmada doküman incelemesi, görüşme ve gözlem gibi nitel veri toplama yöntemleri kullanılır. İzlenen nitel sürecin sonunda, algılar ve olaylar, doğal ortamlarında bütüncül bir biçimde ortaya konmaya çalış1ır (Yıldırım ve Şimşek, 2016).

\subsection{Verilerin Toplanması}

Araştırma verilerinin elde edilmesinde doküman incelemesi yöntemi kullanılmıştır. Doküman incelemesi, araştırma konusu hakkında bilgileri içeren yazılı materyallerin analizi ile gerçekleştirilir. Tek başına ya da diğer veri toplama yöntemleri ile birlikte nitel araştırmada kullanılabilir (Yıldırım ve Şimşek, 2016). Doküman incelemesi, program kayıtları, yazışmalar, resmi yayınlar, günlükler, açık uçlu anketlere verilen cevaplar vb. dokümanların incelenmesini kapsar (Patton, 2014). Bu araştırmada Milli Eğitim Bakanlığı tarafından hazırlanan 1926, 1936, 1948, 1968, 1998, 2005, 2009, 2015, 2017 ve 2018 Hayat Bilgisi öğretim programları doküman olarak kullanılmıştır.

\subsection{Verilerin Analizi}

Araştırma verileri, betimsel analiz yaklaşımı ile çözümlenmiştir. Bu yaklaşıma göre veriler, önceden belirlenmiş olan temalara göre özetlenir ve yorumlanır. Veriler sunulurken, araştırma soruları ile ortaya konulan temalara göre düzenlenebilir. Betimsel analizde amaç, düzenlenmiş ve yorumlanmış olarak bulguları okuyucuya sunmaktır (Yıldırım ve Şimşek, 2016). Bu araştırmada betimsel analiz ile Hayat Bilgisi öğretim programlarının, program ögelerinde ne gibi değişiklikler olduğu belirlenmeye çalışılmıştır.

\section{BULGULAR}

Cumhuriyetin ilanından günümüze kadar kullanılan Hayat Bilgisi öğretim programlarının analizi ile elde edilen veriler, tarihsel süreçteki değişiklikler dikkate alınarak incelenmiş ve program ögeleri kapsamında aşağıdaki bulgulara ulaşılmışıır.

\subsection{Hayat Bilgisi Öğretim Programlarında Hedefler}

Hayat Bilgisi öğretim programlarının hedeflerinde, dönemin beklentilerine ve ihtiyaçlarına uygun olarak değişiklikler yapılmıştır. Hedeflerde gerçekleşen bu değişiklikler Tablo 2'de verilmiştir (MV, 1930; KB, 1936; MEB, 1948, 1969; Vural, 2003, 2005; MEB, 2009, 2015, 2017, 2018). 
Tablo 2. Programların hedeflerinde meydana gelen değişiklikler

\begin{tabular}{|c|c|}
\hline Program & Hedeflerdeki Değişiklikler \\
\hline 1926 & $\begin{array}{l}9 \text { hedef vardır. Çocuğun yakın çevresinde olup bitenlerin bilgisi, inceleme ve gözlem yeteneklerini } \\
\text { arttırmak, faaliyete teşvik etmek, dayanışma ve yardımlaşma duygularını güçlendirmek hedeflerden } \\
\text { bazılarıdır. }\end{array}$ \\
\hline 1936 & $\begin{array}{l}5 \text { hedef vardır. Önemli tarihi olaylara dikkat çekmek ve kavratmak, yurda bağlılık ve milletseverlik } \\
\text { duygu ve bilincini uyandırıp beslemek hedeflerden bazılarıdır. }\end{array}$ \\
\hline 1948 & $\begin{array}{l}5 \text { amaç vardır. Tarihsel oluş fikrini uyandırmak, başka bilim dallarına uygun bir görüş ve inceleme } \\
\text { yoluna hazırlamak bunlardan bazılarıdır. }\end{array}$ \\
\hline \multirow[t]{2}{*}{1968} & $\begin{array}{l}\text { Yakın çevreyi tanıma, yurttaşlık görev ve sorumlulukları, insanların birbirleriyle olan ilişkileri, } \\
\text { ekonomik yaşama fikrini ve yeteneklerini geliştirme ve daha iyi yaşama yeteneklerini geliştirme } \\
\text { yönünden } 23 \text { amaç yer almaktadır. }\end{array}$ \\
\hline & $\begin{array}{l}\text { Demokratik davranışlara sahip bir yurttaş olma; Atatürk'e ve devrimlerine karşı sevgi ve saygı duyan, } \\
\text { milli duyguları kuvvetli, faydalı birey olma vurgusu vardır. } \\
\text { Hedefler ilk kez öğrenciye dönük olarak ifade edilmiştir. }\end{array}$ \\
\hline \multirow[t]{2}{*}{1998} & $\begin{array}{l}\text { Genel hedeflerle birlikte ilk kez sınıflar düzeyinde özel hedeflere ve ünitelere ait hedef ve } \\
\text { davranışlara yer verilmiştir. Ilk kez belirtke tablosu kullanılmıştır. Belirtke tablosu ve hedeflerin } \\
\text { davranışlarla detaylandırılması, programın davranış̧ yaklaşıma dayalı hazırlandığını } \\
\text { göstermektedir. }\end{array}$ \\
\hline & $\begin{array}{l}\text { Genel hedeflerde ulusal değerlere bağlılıkla birlikte ilk kez eleştirel ve yaratıcı düşünme, ülke ve } \\
\text { dünya olaylarına duyarlı olma, uzayı tanıma, bilinçli bir tüketici olma, teknolojik yeniliklerden } \\
\text { yararlanma ve turizmin önemi yer almaktadır. }\end{array}$ \\
\hline \multirow[t]{4}{*}{$2005 / 2009$} & Genel hedefler yoktur. Hedef ve davranışlar yerine kazanımlar yer almaktadır. \\
\hline & Program, yapılandırmacılık felsefesine dayanmaktadır. \\
\hline & $\begin{array}{l}\text { Kazanımlarda diğer derslerle ilişkilendirmeler yapıılmıştır. Atatürkçülük kazanımları ve ara disiplin } \\
\text { alanlarına ait kazanımlar yer almaktadır. (Afet eğitimi, girişimcilik...) }\end{array}$ \\
\hline & Öğrencilerin bilgi teknolojilerini kullanma ve girişimcilik becerilerini kazanmaları hedeflenmiştir. \\
\hline \multirow{3}{*}{2015} & Tüm sınıflarda toplam 146 kazanım vardır. \\
\hline & Etkinlikler yoluyla, belirlenen beceriler ve değerleri kazandırma hedeflenmiştir. \\
\hline & Atatürkçülük kazanımları, ara disiplin kazanımları ve diğer derslerle ilişkilendirmeler kaldırılmıştır. \\
\hline $2017-2018$ & $\begin{array}{l}2017 \text { programında } 143 \text { kazanım, } 2018 \text { programında } 148 \text { kazanım vardır. } \\
\text { Etkinlikler yoluyla öğrenciye, birey, toplum ve doğa ekseninde temel bilgi, yaşam becerileri, anahtar } \\
\text { yetkinlikler ve değerlerin kazandırılması hedeflenmiştir. }\end{array}$ \\
\hline
\end{tabular}

Tablo 2 incelendiğinde Hayat Bilgisi öğretim programlarının hedef ögesinde meydana gelen değişiklikler görülmektedir. 1926, 1936 ve 1948 programlarında amaçlar belirlenirken çocuğun yakın çevresi ve ulusal değerlerin dikkate alındığı, amaçların öğrenci davranışına dönük olarak ifade edilmediği görülmektedir. 1968 programında ise hedefler ilk kez başlıklar altında toplanmış ve öğrenci davranışlarına dönük olarak ifade edilmiştir. Ayrıca demokratik davranışlara sahip bir yurttaş olma; Atatürk'e ve devrimlerine karşı sevgi ve saygı duyan, milli duyguları kuvvetli, faydalı birey olma vurgusu yapılmıştır. 1998 programında 26 genel hedefle birlikte ilk kez sınıflar düzeyinde özel hedeflere (toplam 61 özel hedef) ve ünite hedefleri ve davranışlarına (234 ünite hedefi, 1074 davranış) yer verilmiştir. Hedeflere ulaşmayı kolaylaştırmak için belirtke tablosu ilk kez kullanılmıştır.

2005 programı ile birlikte yapılandırmacı felsefeden etkilenerek programlar hazırlanmaya başlanmıştır. Programda hedef ve davranışlar yerine, kazanımlar yer almıştır. 2005 programında 376 kazanım, 2009 programında 292 kazanım vardır. Kazanımlarda diğer derslerle ilişkilendirmeler yapılmış, Atatürkçülük kazanımları ve afet eğitimi, girişimcilik, özel eğitim gibi ara disiplin alanlarına ait kazanımlara yer verilmiştir. Önceki programlardan farklı olarak öğrencilerin bilgi teknolojilerini kullanma ve girişimcilik becerilerini kazanmaları hedeflenmiştir. Programda bilişsel ve duyuşsal alanda kazanımların yer almasına rağmen, psikomotor alanda kazanımlara yer verilmediği görülmüsstür.

2005 programından sonra hazırlanan programlarda kazanım sayısının giderek azaldığı görülmektedir. 2005 programında 376 olan kazanım sayısı, 2009 programında 292, 2015 programında 146, 2017 programında 143 ve 2018 programında 148 olmuştur. Etkinlikler yoluyla, belirlenen beceriler ve değerleri kazandırmanın hedeflendiği 2015, 2017 ve 2018 programlarında Atatürkçülük kazanımları, ara disiplin kazanımları ve diğer derslerle ilişkilendirmeler kaldırılmıştır. Yapılandırmacı yaklaşımın temel alındığına dair bir ifadenin geçmemesi yapılandırmacı anlayıştan programın uzaklaşma eğilimi gösterdiği; ayrıca 2005 ve sonrasında hazırlanan programlardaki kazanımlarda ulusal değerlerin etkisinin önceki programlar kadar hissedilmemesi, programın kültürel ve sosyal değer aktarımından uzaklaştı̆̆ının göstergeleri olarak görülebilir. 


\subsection{Hayat Bilgisi Öğretim Programlarında İçerik}

Cumhuriyetin ilanından günümüze kadar kullanılan Hayat Bilgisi öğretim programlarının içeriklerinde meydana gelen değişiklikler Tablo 3'te verilmiştir (MV, 1930; KB, 1936; MEB, 1948, 1969; Vural, 2003, 2005; MEB, 2009, 2015, 2017, 2018).

Tablo 3. Programların içeriklerinde meydana gelen değişiklikler

\begin{tabular}{|c|c|}
\hline Program & İçeriklerdeki Değişiklikler \\
\hline 1926 & $\begin{array}{l}\text { İcerik, konular listesi halindedir. Çocuğun yakın çevresi, mevsimlerde meydana gelen değişiklikler } \\
\text { ve yapılan işler, cumhuriyet vurgusu ve ulusal değerler, üzerinde durulmuștur. }\end{array}$ \\
\hline \multirow[t]{4}{*}{1936} & Ir listesi halindedir, ancak azaltılmıştır. \\
\hline & z kullanılmıştır. \\
\hline & nlerine bağlılık, üzerinde en çok durulan konulardır. \\
\hline & $\begin{array}{l}\text { Yeni konular: telefon, yangın, bahar bayramı, askerlik, hava gözlemleri, yurda ve ulusa karşı sevgi, } \\
\text { saygı, bağl11k. }\end{array}$ \\
\hline \multirow[t]{3}{*}{1948} & $\begin{array}{l}\text { İçerik, tekrar yoğunlaşmıştır ve konular listesi halindedir. Bilgi öğretimi esastır. Demokrasi, yerli } \\
\text { malı ve tutumlu olma değerleri vurgulanmıştır. }\end{array}$ \\
\hline & $\begin{array}{l}\text { er konu, bir "hayat safhası"dır. Konuların alt başlıkları ise "hayat levhaları" olarak ele alınır. Her } \\
\text { nnunun sonuna eğitsel sonuçlar eklenmiştir. }\end{array}$ \\
\hline & $\begin{array}{l}\text { Yeni konular:19 Mayıs Bayramı, Artırma ve yerli malı haftası, Atatürk ve İnönü’nün yaşamı, } \\
\text { Kurtuluş Savaşı, radyo. }\end{array}$ \\
\hline \multirow[t]{4}{*}{1968} & vardir. \\
\hline & 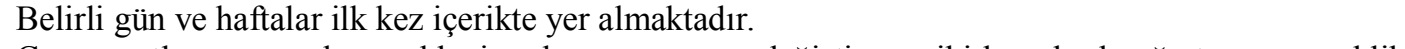 \\
\hline & $\begin{array}{l}\text { vre şartlarına göre konu ekleyip çıkarma, sırasını değiştirme gibi konularda öğretmene esneklik } \\
\text { ınnmıştır. }\end{array}$ \\
\hline & $\begin{array}{l}\text { Yeni konular: eğitsel kollar, televizyonla haberleşme, } 10 \text { Kasım anma töreni, Atatürk devrimleri, } \\
\text { Dünyamızın oluşumu, gökyüzü yolculuğu, çiftçinin hayatı, enerjiler }\end{array}$ \\
\hline \multirow[t]{3}{*}{1998} & dan ols \\
\hline & \\
\hline & $\begin{array}{l}\text { ni konular: evde ve okulda demokrasi, insan hakları ve hürriyetleri, sorumluluklar, bilinçli } \\
\text { keticilik, uzay araştırmaları }\end{array}$ \\
\hline \multirow[t]{3}{*}{$2005 / 2009$} & $\begin{array}{l}\text { İçerik, ilk kez öğrenme alanları (birey, toplum ve doğa) halinde ve tematik yaklaşım kullanılarak } \\
\text { oluşturulmuştur. Üç sınıfta da aynı temalar (Okul heyecanım, benim eşsiz yuvam, dün, bugün ve } \\
\text { yarın) vardır. } \\
\text { İçerik düzenlemede sarmal yaklaşım/spiral izlenmiştir. }\end{array}$ \\
\hline & arak daha evrensel hir hoyut kazanmıs \\
\hline & $\begin{array}{l}\text { neğin; İnsanlığa hizmet etmiş kişiler, etik davranışlar, ülkelerin bayrakları, farklı ülkelerin } \\
\text { cuklarının giyimi ve oyunları, iletişim teknolojileri, bilgisayar... Buna bağlı olarak, ulusal } \\
\text { gerlerde azalma olduğu söylenebilir. }\end{array}$ \\
\hline 2015 & $\begin{array}{l}\text { İçerik, ünite temelli yaklaşım ile oluşturulmuştur. Her üç sınıf düzeyi için aynı isimle "Ben ve } \\
\text { Okulum", "Ailem ve Evim", "Sağlıklı Hayat", "Güvenli Hayat", "Ülkemi seviyorum" ile "Doğa ve } \\
\text { çevre" şeklinde altı ünite belirlenmiştir. } \\
\text { İçeriğin sarmal yaklaşımla düzenlendiği ifade edilmemiş ancak bazı kazanımların üst sınıfta } \\
\text { tekrarlandığı belirtilmş̧tir. }\end{array}$ \\
\hline \multirow[t]{3}{*}{$2017-2018$} & $\begin{array}{l}\text { İçerik, genel amaçlar, temel yaşam becerileri, değerler, kavramlar, ünite ve kazanım bağlamında } \\
\text { yapılandırılmışır. }\end{array}$ \\
\hline & te temelli yaklaşım esas alınmıştır. Üç sınıfta da aynı isimle "Okulumuzda Hayat", "Evimizde \\
\hline & Hayat", "Güvenli Hayat", “Ülkemizde Hayat" ve "Doğada Hayat" şeklinde altı \\
\hline
\end{tabular}

Tablo 3 incelendiğinde programların içeriklerinde önemli değişikliklerin olduğu görülmektedir. 1926, 1936 ve 1948 programlarında içerik, konular listesi şeklinde düzenlenmiştir. Çocuğun yakın çevresi, ulusalcılık, Türk devrimlerine bağl1lık, üzerinde durulan konulardır. 1936 programında yıllık plan ve ünite planı ilk kez kullanılmıştır. 1948 programı ile bilgi öğretimi esas alınarak içerik yoğunlaştırılmış, demokrasi ve tutumlu olma değerleri vurgulanmıştır. İçerik düzenlemede farklı bir yaklaşım izlenerek; her konu, bir "hayat safhası"; konuların alt başlıkları ise "hayat levhaları" olarak ele alınmış; konu sonlarına eğitsel sonuçlar yazılmıştır. 1968 programında içerik ilk kez üniteler şeklinde düzenlenmiştir. Çevre şartlarına göre konu ekleyip çıkarma, konu sırasını değiştirme gibi konularda öğretmene esneklik tanınmıştır. Belirli gün 
ve haftalar ilk kez içerikte yer almaktadır. 1998 programında içerik, kapsamlı ünite planlarından oluşmuştur ve içerik düzenlenirken doğrusal programlama yaklaşımı (aşamalılık) kullanılmıştır.

2005 ve sonrasında hazırlanan programların içeriklerinde de birtakım farklılıklar görülmektedir. 2005 ve 2009 programlarında içerik, ilk kez öğrenme alanları halinde ve tematik yaklaşım kullanılarak oluşturulmuştur. Öğrenme alanları olarak birey, toplum ve doğa belirlenmiş; üç sınıfta da "Okul heyecanım, Benim eşsiz yuvam, Dün, bugün ve yarın” olmak üzere aynı temalar kullanılmıştır. İçerik düzenlemede sarmal yaklaşım/spiral izlenmiştir. Ayrıca konular çocuğun yakın çevresinden ve ulusallıktan uzaklaşarak daha evrensel bir boyut kazanmıştır. Örneğin; İnsanlığa hizmet etmiş kişiler, etik davranışlar, ülkelerin bayrakları, farklı ülkelerin çocuklarının giyimi ve oyunları, iletişim teknolojileri, bilgisayar gibi konular içerikte yer almıştır. 2015, 2017 ve 2018 programlarında içerik, ünite temelli yaklaşım ile düzenlenmiş; üç sınıfta da içerik, aynı 6 üniteden oluşmuştur. İçeriğin sarmal yaklaşımla düzenlendiği ifade edilmemiş ancak bazı kazanımların üst sınıfta tekrarlandığı belirtilmiştir. 2017 ve 2018 programlarında içerik, genel amaçlar, temel yaşam becerileri, değerler, kavramlar, ünite ve kazanım bağlamında yapılandırılmıştır. 2015 programında yer alan "Ülkemi Seviyorum" ünitesi; 2017 ve 2018 programlarında "Ülkemizde Hayat" adıyla yer almıştır.

\subsection{Hayat Bilgisi Öğretim Programlarında Öğrenme-Öğretme Süreci}

Cumhuriyetin ilanından günümüze kadar kullanılan Hayat Bilgisi öğretim programlarının öğrenmeöğretme süreçlerinde meydana gelen değişiklikler Tablo 4'te verilmiştir (MV, 1930; KB, 1936; MEB, 1948, 1969; Vural, 2003, 2005; MEB, 2009, 2015, 2017, 2018).

Tablo 4. Programların öğrenme-öğretme süreçlerinde meydana gelen değişiklikler

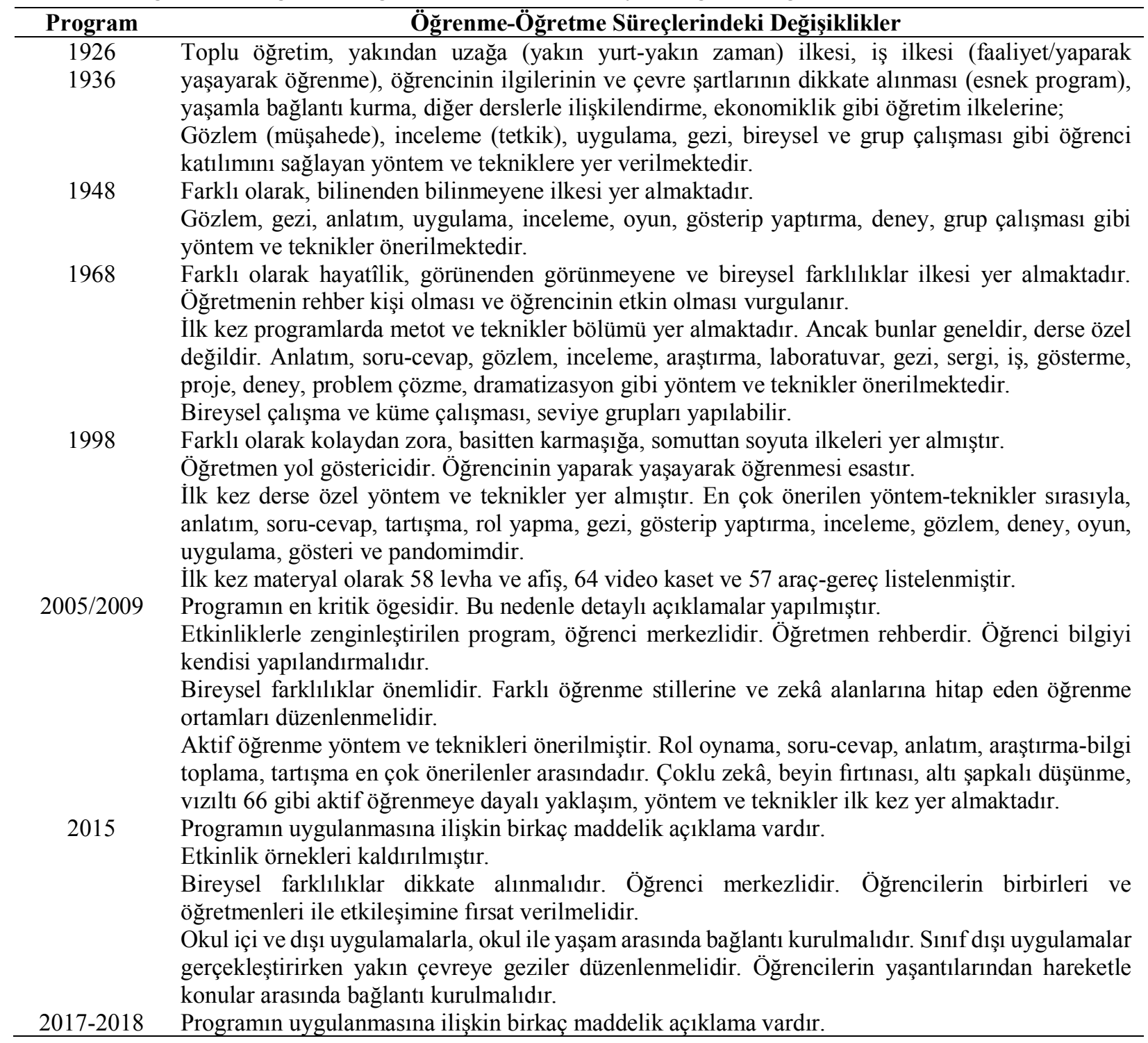


Okul içi ve dışı uygulamalarla dersin işlenmesine özen gösterilmelidir.

Etkinliklerle, okul ve yaşam arasında bağlantı kurulmalıdır. Etkinlikler hazırlanırken öğrencilerin ilgi, istek ve ihtiyaçları dikkate alınmalı; etkinlikler yoluyla, temel yaşam becerilerinin geliştirilmesi ve değerlerin kazandırılmasına özen gösterilmelidir.

Doğa içerikli kazanımlarda basit düzeyde deneyler yaptırılabilir. Afiş, poster, pano, tablo, grafik vb. materyaller ile araştırma sonuçlarını sınıfta paylaşması desteklenmelidir.

Tablo 4 incelendiğinde programların öğrenme-öğretme süreçlerinde önemli değişikliklerin olduğu görülmektedir. 1926 ve 1936 programlarında öğrenme-öğretme süreci boyutu olmamakla birlikte, bu süreçte işe koşulacak toplu öğretim, yakından uzağa (yakın yurt-yakın zaman) ilkesi, iş ilkesi (faaliyet/yaparak yaşayarak öğrenme), ekonomiklik, öğrencinin ilgilerinin ve çevre şartlarının dikkate alınması (esnek program), yaşamla bağlantı kurma, diğer derslerle ilişkilendirme, ekonomiklik gibi öğretim ilkelerine; gözlem (müşahede), inceleme (tetkik), uygulama, gezi, bireysel ve grup çalışması gibi öğrencinin katılımını sağlayan yöntem ve tekniklere yer verilmektedir. 1948 programında, önceki programlardan farklı olarak; bilinenden bilinmeyene ilkesine yer verilmiş, gözlem, gezi, anlatım, uygulama, inceleme, oyun, gösterip yaptırma, deney, grup çalışması gibi yöntem ve teknikler önerilmiştir. 1968 programında, farklı olarak hayatîlik, görünenden görünmeyene ve bireysel farkl1lıklar ilkesine yer verilmiş, öğretmenin rehber kişi olması ve öğrencinin etkin olması vurgulanmıştır. Bireysel çalışma, küme çalışması, seviye gruplarının yapılabileceği belirtilmiştir. İlk kez 1968 programında metot ve teknikler bölümüne yer verilmiştir. Ancak bunlar geneldir, derse özel değildir. Anlatım, soru-cevap, gözlem, araştırma, inceleme, sergi, iş, gezi, gösterme, proje, laboratuvar, deney, problem çözme, dramatizasyon gibi yöntem ve teknikler önerilmiştir. 1998 programında, farklı olarak kolaydan zora, basitten karmaşı̆̆a, somuttan soyuta ilkeleri yer almıştır. İlk kez 1998 programında derse özel yöntem ve teknikler yer almıştır. En çok önerilen yöntem-teknikler sırasıyla, anlatım, soru-cevap, tartışma, rol yapma, gezi, gösterip yaptırma, inceleme, gözlem, deney, oyun, uygulama, gösteri ve pandomimdir. İlk kez materyal olarak öğrenme-öğretme sürecinde kullanılabilecek 58 levha ve afiş, 64 video kaset ve 57 araç-gereç listelenmiştir.

2005/2009 programlarında, öğrenme-öğretme süreci programın en kritik ögesidir. Bu nedenle süreçle ilgili detaylı açıklamalar yapılmıştır. Etkinliklerle zenginleştirilen program, öğrenci merkezlidir. Öğretmen rehberdir. Öğrenci bilgiyi kendisi yapılandırmalıdır. Bireysel farklılıklar önemlidir. Farklı öğrenme stillerine ve zekâ alanlarına hitap eden öğrenme ortamları düzenlenmelidir. Aktif öğrenme yöntem ve teknikleri önerilmiştir. Rol oynama, soru-cevap, anlatım, araştırma-bilgi toplama, tartışma en çok önerilenler arasındadır. Çoklu zekâ, altı şapkalı düşünme, beyin firtınası, vızıltı 66 gibi aktif öğrenmeye dayalı yaklaşım, yöntem ve teknikler ilk kez yer almaktadır. 2005/2009 programlarında. yapılandırıcı yaklaşım esas alındığı belirtilmesine rağmen; 2015, 2017 ve 2018 programlarında, programların dayandırıldığ 1 felsefe ifade edilmezken, programların öğrenci merkezli olduğu belirtilmektedir. Bununla birlikte 2015, 2017 ve 2018 programlarında, programın uygulanmasına ilişkin detaylı açıklamalar yerine birkaç maddelik açıklama yapılmıştır. Etkinlik örnekleri kaldırılmış, okul içi ve dışı uygulamalarla yaşamla bağlantı kurma esas alınmıştır.

\subsection{Hayat Bilgisi Öğretim Programlarında Ölçme-Değerlendirme}

Cumhuriyetin ilanından günümüze kadar kullanılan Hayat Bilgisi öğretim programlarının ölçmedeğerlendirme ögesinde meydana gelen değişiklikler Tablo 5 'te verilmiştir (MV, 1930; KB, 1936; MEB, 1948, 1969; Vural, 2003, 2005; MEB, 2009, 2015, 2017, 2018).

Tablo 5 incelendiğinde programların ölçme-değerlendirme ögesinde önemli değişikliklerin yapıldığı görülmektedir. 1926, 1936 ve 1948 Hayat Bilgisi programlarında ölçme ve değerlendirmeye ilişkin açıklama yoktur. 1968 ve 1998 programlarında ürün odaklı bir ölçme değerlendirme anlayışı benimsenmiştir. 1968 programında günlük, haftalık, aylık değerlendirme; ara değerlendirme, dönem ve yıl sonu değerlendirmelerinin sırasıyla yapılması belirtilmiştir. Bu değerlendirmeler, öğretmen katılımı ile yapılabildiği gibi öğrencinin kendini değerlendirmesi, küme ve grup çalışmalarının değerlendirilmesi şeklinde de yapılabilir. 1998 programında ilk kez derse özel ölçme-değerlendirme ögesi yer almaktadır. Bu programda, klasik ölçme ve değerlendirme araçları ile gözlem formu, ölçme-değerlendirme amaçlı kullanılabilir. Öğretmenler, belirtke tablosunu kullanarak ölçme soruları / gözlem formu hazırlayabilir. 2005, 2009 ve 2015 programlarında, ürün odaklı ve süreç odaklı ölçme-değerlendirme anlayış1 benimsenmiştir. Klasik ölçme-değerlendirme araçlarının yanı sıra yapılandırmacı öğrenmeye dayalı alternatif/çoklu ölçme-değerlendirme yaklaşımları kullanılır. 2017 programında değerlendirme, üç aşamada tanıma, izleme ve ürün odaklı değerlendirme olarak düzenlenmiştir. 2018 programında ise ölçme- 
değerlendirme sürecinde esneklik ve çeşitlilik anlayışına dayalı çok odaklı ölçme değerlendirmenin esas alındığ 1 ifade edilmiştir.

Tablo 5. Programların ölçme-değerlendirme ögesinde meydana gelen değişiklikler

\begin{tabular}{|c|c|}
\hline Program & Ölçme-Değerlendirme Ögesindeki Değişiklikler \\
\hline 1926 & Ölçme-değerlendirmeye ilişkin açıklama bulunmamaktadır. \\
\hline 1936 & Gözlem defteri tutma, koleksiyon yapma, yıl sonu yapılan sınıf ve okul sergisi; değerlendirme amaçlı \\
\hline 1948 & kullanılabilir. \\
\hline \multirow{2}{*}{1968} & Değerlendirmeye ilk kez yer verilmiştir. \\
\hline & $\begin{array}{l}\text { Değerlendirme, sürekli bir eylemdir. Günlük, haftalık, aylık değerlendirme; ünite işlenişi sırasında } \\
\text { ara değerlendirme, dönem ve yıl sonu değerlendirmeleri olarak sırası geldikçe yapılmalıdır. } \\
\text { Öğretmen katılımı ile yapılabildiği gibi öğrencinin kendini değerlendirmesi, küme ve grup } \\
\text { çalışmalarının değerlendirilmesi şeklinde de yapılabilir. Öğrencinin başarısını, kendi gelişimine göre } \\
\text { değerlendirmek esastır. }\end{array}$ \\
\hline \multirow[t]{3}{*}{1998} & İlk kez derse özel ölçme-değerlendirme ögesi yer almaktadır. \\
\hline & $\begin{array}{l}\text { Ürün odaklı değerlendirme anlayışı hâkimdir. Klasik ölçme ve değerlendirme araçları ile gözlem } \\
\text { formu kullanılır. }\end{array}$ \\
\hline & $\begin{array}{l}\text { Öğretmenler, uygun ölçme araçlarını seçebilir ve çeşitlendirebilir; belirtke tablosunu kullanarak } \\
\text { ölçme soruları / gözlem formu hazırlayabilir. }\end{array}$ \\
\hline 2005/2009 & Ürün odaklı ve süreç odaklı ölçme-değerlendirme anlayışı yer almaktadır. \\
\hline \multirow[t]{2}{*}{2015} & $\begin{array}{l}\text { Klasik ölçme-değerlendirme araçlarının yanı sıra yapılandırmacı öğrenmeye dayalı alternatif/çoklu } \\
\text { ölçme-değerlendirme yaklaşımları kullanılır. Öz değerlendirme, ürün dosyası, dereceli puanlama } \\
\text { anahtarı, proje, performans değerlendirme, tutum ölçekleri bunlardan bazılarıdır. }\end{array}$ \\
\hline & $\begin{array}{l}\text { Kazanımların gerçekleşme düzeyi ve öğrencilerin gelişimi süreç içerisinde izlenmeli, eksiklikleri } \\
\text { gidermek ve öğrenmeyi geliştirmek amacıyla düzenlemeler yapılmalıdır. }\end{array}$ \\
\hline 2017 & $\begin{array}{l}\text { Ölçme-değerlendirme anlayışı olarak, öğrencilerin süreç içerisinde izlenmesi, , öğrencilerde anlamlı } \\
\text { ve kalıcı öğrenmenin desteklenmesi ve ögrenme güçlüklerinin giderilmesi amacıyla geri bildirimin } \\
\text { sağlanmasına yönelik bir anlayış benimsenmiştir. }\end{array}$ \\
\hline & $\begin{array}{l}\text { Tanıma, izleme ve ürün odaklı değerlendirme yapılmaktadır. } \\
\text { Öz değerlendirme, akran ve grup değerlendirme yoluyla, öğrencilerin kendi öğrenmelerini } \\
\text { değerlendirmeleri önemlidir. } \\
\text { Hazırbulunuşluk testleri, gözlem, görüşme formları, yetenek testleri kullanılabilir. }\end{array}$ \\
\hline 2018 & $\begin{array}{l}\text { Ölçme-değerlendirme sürecinde esneklik ve çeşitlilik anlayışı olmalıdır. Çok odaklı ölçme- } \\
\text { değerlendirme esastır. } \\
\text { Öğretmen ve öğrencilerin katılımıyla ölçme ve değerlendirme uygulamaları gerçekleştirilir. İlgi, } \\
\text { tutum, değer ve başarı gibi özelliklerin süreç içindeki değişimlerini dikkate alan ölçümler kullanmak } \\
\text { esastır. }\end{array}$ \\
\hline
\end{tabular}

\section{TARTIŞMA ve SONUÇ}

Bu araştırmada, Cumhuriyetin kuruluşundan itibaren uygulanan 1926, 1936, 1948, 1968, 1998, 2005, 2009, 2015, 2017 ve 2018 Hayat Bilgisi öğretim programlarının, eğitim programlarının temel ögelerini oluşturan hedef, içerik, öğrenme-öğretme süreci ve ölçme- değerlendirme ögeleri esas alınarak değerlendirilmesi amaçlanmıştır. Bu amaçla Hayat Bilgisi öğretim programlarının ögelerinde, betimsel analiz yoluyla, tarihsel süreç içerisinde uğradığı değişiklikler ele alınmaya çalışılmıştır. Araştırmadan elde edilen bulgulara göre programların dört boyutunda da önemli değişiklikler olduğu görülmektedir.

Programların hedef ögesi ile ilgili olarak, 1926, 1936 ve 1948 programlarında amaçlar belirlenirken çocuğun yakın çevresi ve ulusal değerlerin dikkate alındığı, amaçların öğrenci davranışına dönük olarak ifade edilmediği görülmektedir. Türe (2013) çalışmasında, 1936 ilkokul programının, ekonomik, tarihi, dil, sosyal ve kültürel yönlerden ulusal değerlerin yeniden yaratıldığı ve millileştirildiği bir dönemin yansımalarını taşıdığını ifade etmiştir. 1968 programında hedefler ilk kez başlıklar altında toplanmış ve öğrenci davranışlarına dönük olarak ifade edilmiştir. Ayrıca demokratik davranışlara sahip bir yurttaş olma; Atatürk'e ve devrimlerine karşı sevgi ve saygı duyan, milli duyguları kuvvetli, faydalı birey olma vurgusu yapılmıştır. 1998 programında genel hedeflerle birlikte ilk kez sınıflar düzeyinde özel hedeflere, ünite hedefleri ve davranışlarına yer verilmiştir. Hedeflere ulaşmayı kolaylaştırmak için belirtke tablosu ilk kez kullanılmıştır. Belirtke tablosunun kullanılması ve hedeflerin davranışlarla detaylandırılması ile 1998 programının, davranışçı yaklaşımın etkisinde hazırlandığı söylenebilir. Zira Güven (2010) araştırmasında, 1998 programında bilginin, konu merkezli olarak birbirinden kopuk ve statik bir yaklaşımla öğretmen tarafından öğrencilere aktarıldığını, bu nedenle öğrencilerden çok, öğretmenin merkezde olduğunu; öğrencilerin verilen bilgileri ezberlemek için aktif olduklarını belirtmiştir. 
2005 programı ile birlikte yapılandırmacı felsefeden etkilenerek programlar hazırlanmaya başlanmıştır. Programda hedef ve davranışlar yerine, kazanımlar yer almaktadır. Tay ve Baş (2015) araştırmasında, 2005 yılına kadar davranışçı yaklaşımın etkisiyle "hedef davranış" olarak geçen ifadenin, 2005 ve sonrasında hazırlanan programlarda "kazanım" olarak değiştiğini belirtmiş ve bu değişimin ana nedenini, yapılandırmacı yaklaşımın benimsenmesi olarak ifade etmiştir. 2005 programı ile kazanımlarda diğer derslerle ilişkilendirmeler yapılmış, Atatürkçülük kazanımları ve afet eğitimi, girişimcilik, özel eğitim gibi ara disiplin alanlarına ait kazanımlara yer verilmiştir. Bilinenin aksine, diğer derslerle ilişkilendirmelerin ilk kez 2005 programı ile yapılmadığı söylenebilir. Zira 1926 programında yer alan "İrtibat Cedvelleri" incelendiğinde, Hayat Bilgisi dersinde işlenen konuların diğer derslerde nasıl ele alınacağının anlatıldığı görülmektedir. Bıkmaz (2013b), 1926 programında Hayat Bilgisi mihverliğinde ele alınan bir konunun diğer derslerde de, dersin özelliğine göre ele alınmasıyla, öğrenilenlerin ilişkilendirilmesinin, anlamlı ve bütüncül öğrenmenin sağlandığını belirtmiştir. Önceki programlardan farklı olarak 2005/2009 programlarında, öğrencilerin bilgi teknolojilerini kullanma ve girişimcilik becerilerini kazanmaları hedeflenmiştir. Programda bilişsel ve duyuşsal alanda kazanımların olmasına rağmen, psikomotor alandaki kazanımlara yer verilmediği görülmüştür. Gözütok (2013) çalışmasında, üç yıllık Hayat Bilgisi dersi programında yalnızca iki psikomotor kazanımın yer aldığını belirtmiştir. Türkyılmaz (2011) tarafından yapılan araştırmada, programdaki kazanımların dersin genel amaçlarına uygun olduğu ve Atatürkçülük konularıyla ilişkilendirildiği, fakat ara disiplin kazanımlarıyla yeterli derecede ilişkilendirilmediği sonucuna ulaşılmıştır. Öztürk ve Kalafatçı (2017) tarafindan yapılan araştırmada, kazanımların anlaşılır ve net olmakla birlikte, öğrencilerin gerçek yaşamlarıyla birebir örtüşmediği, ilgi çekici olmadığı, öğrencilerde öğrenme ve bilimsel araştırma merakını artırıcı, eleştirel ve yaratıcı düşünme becerisini geliştirici nitelikte hazırlanmadığı ve kazanımlar için ders süresinin yetersiz olduğu sonucuna ulaşılmıştır.

2005 programından sonra hazırlanan programlarda kazanım sayısının giderek azaldığı görülmektedir. Tay ve Baş (2015) çalışmalarında, Hayat Bilgisi ders saatlerinin azaltılmasının, kazanımların azalma nedeni olabileceğini belirtmiştir. Etkinlikler yoluyla, belirlenen beceriler ve değerleri kazandırmanın hedeflendiği 2015, 2017 ve 2018 programlarında Atatürkçülük kazanımları, ara disiplin kazanımları ve diğer derslerle ilişkilendirmeler kaldırılmıştır. Son üç programda, yapılandırmacı yaklaşımın temel alındığına dair bir ifadenin geçmemesi, ayrıca 2005 ve sonrasında hazırlanan programlardaki kazanımlarda ulusal değerlerin etkisinin önceki programlar kadar hissedilmemesi, dikkati çeken diğer konulardır. Gözütok (2010) araştırmasında, ulusal değerler kazandırmaya ve demokratik kültür oluşturmaya hizmet eden ifadeler açısından 1998 ve 2005-2009 Hayat Bilgisi programları karşılaştıııldığında, 2005-2009 programının sayısal ve niteliksel derinlik bakımından çok zayıf kaldığını belirtmiştir. Demir (2016) öğretmen adayları ile yaptığı araştırmasında, öğretmen adaylarının Hayat Bilgisi öğretim programında bulunmasını en gerekli gördükleri 5 kazanımdan üçünün "Atatürk ve cumhuriyetin değerine ilişkin kazanımlar", "Vatanın birliği, bütünlüğü ve bölünmezliği ilgili kazanımlar" ve "Türk bayrağı, istiklal marşı ve andımız ile ilgili kazanımlar" olduğunu saptamıştır. Ulusal değerlere dair kazanım önerilerinin çoğunlukta olması nedeniyle, ulusal değerlerin öğrencilere kazandırılmasında Hayat Bilgisi öğretim programlarından önemli bir beklenti içinde olunduğu söylenebilir.

Programların içerik ögesinde, 1926, 1936, 1948, 1968 programlarında yoğun içerik olmasına rağmen, 1998 ve sonraki programlarda içeriğin yoğunluğu kısmen azaltılmıştır. 1926, 1936 ve 1948 programlarında içeriğin konular listesi şeklinde düzenlendiği belirlenmiştir. Çocuğun yakın çevresi, ulusalcılık, Türk devrimlerine bağlılık, içerikte üzerinde durulan konulardan bazılarıdır. 1936 programında yıllık plan ve ünite planı ilk kez kullanılmışır. 1948 programı ile bilgi öğretimi esas alınarak içerik yoğunlaştırılmış, demokrasi, yerli malı ve tutumlu olma değerleri vurgulanmıştır. Programdaki yerli malı ve tutumlu olma vurgusunun, özellikle II. Dünya Savaşı yıllarında ortaya çıkan kıtlık nedeniyle yaşanan sorunlar neticesinde programa yansıtıldığı düşünülebilir. 1948 programında içerik düzenlemede farklı bir yaklaşım izlenerek; her konu, bir "hayat safhası"; konuların alt başlıkları ise "hayat levhaları" olarak ele alınmış; konu sonlarına eğitsel sonuçlar yazılmıştır. 1968 programında içerik ilk kez üniteler şeklinde düzenlenmiş ve çevre şartlarına göre konu ekleyip çıkarma, konu sırasını değiştirme gibi konularda öğretmene esneklik tanınmıştır. Belirli gün ve haftalar ilk kez içerikte yer almıştır. 1998 programında içerik, kapsamlı ünite planlarından oluşmuştur ve içerik düzenlenirken doğrusal programlama yaklaşımı (aşamalılık) kullanılmıştır.

2005 ve sonrasında hazırlanan programların içeriklerinde de birtakım farkl1lıklar görülmektedir. 2005 ve 2009 programlarında içerik, ilk kez öğrenme alanları halinde ve tematik yaklaşım kullanılarak oluşturulmuştur. Öğrenme alanları olarak birey, toplum ve doğa belirlenmiş; üç sınıfta da "Okul heyecanım, 
Benim eşsiz yuvam, Dün, bugün ve yarın” olmak üzere aynı temalar kullanılmıştır. İçerik düzenlemede sarmal yaklaşım/spiral izlenmiştir. Ayrıca konular çocuğun yakın çevresinden ve ulusallıktan uzaklaşarak daha evrensel bir boyut kazanmıştır. Tuncer (2009) öğretmenlerle yaptığı araştırmasında, temalarla ilgili olumlu yönde görüşlerin olduğu ve tematik yaklaşımın benimsenmesinin olumlu olduğu sonucuna ulaşmıştır. Öztürk ve Kalafatçı (2017) tarafindan yapılan çalışmada öğretmenler, temaların içerik olarak yeterli bilgi taşımadıklarını, öğrencilerin ilgisini çeken konu ve metinler içermediğini, bilgi ve kavramların öğrencilerin hazırbulunuşluk seviyelerine uygun olmadığını belirtmişlerdir. Ayrıca temalarda yer alan metinlerin kazanımlarla örtüştüğünü, basitten karmaşığa, kolaydan zora ve yakından uzağa ilkelerine uygun hazırlandığını ve farklı öğretim yöntem ve tekniklerini uygulamak için elverişli olduğunu ifade etmişlerdir.

2015, 2017 ve 2018 programlarında içerik, ünite temelli yaklaşım ile düzenlenmiş; üç sınıfta da içerik, aynı 6 üniteden oluşmuştur. İçeriğin sarmal yaklaşımla düzenlendiği ifade edilmemiş ancak bazı kazanımların üst sınıfta tekrarlandığ belirtilmiştir. 2017 ve 2018 programlarında içerik, genel amaçlar, temel yaşam becerileri, değerler, kavramlar, ünite ve kazanım bağlamında yapılandırılmıştır. 2015 programında yer alan "Ülkemi Seviyorum" ünitesi; 2017 ve 2018 programlarında "Ülkemizde Hayat" adıyla yer almıştır. Bu durum, programdaki ulusal değerlerde hissedilen azalmaya bir örnek gösterilebilir.

Programların öğrenme-öğretme süreçlerinde önemli değişikliklerin olduğu görülmektedir. Öğrenmeöğretme sürecinde 1926, 1936, 1948 ve 1968 programlarında yakından uzağa ilkesi göz önüne alınarak gezi-gözlem-ve incelemeye daha fazla yer verilmiştir. 1926 ve 1936 programlarında öğrenme-öğretme süreci boyutu olmamakla birlikte, bu süreçte işe koşulacak toplu öğretim, yakından uzağa (yakın yurt-yakın zaman) ilkesi, iş ilkesi (faaliyet/yaparak yaşayarak öğrenme), ekonomiklik, öğrencinin ilgilerinin ve çevre şartlarının dikkate alınması (esnek program), yaşamla bağlantı kurma, diğer derslerle ilişkilendirme, ekonomiklik gibi öğretim ilkelerine; gözlem (müşahede), inceleme (tetkik), uygulama, gezi, bireysel ve grup çalışması gibi öğrencinin katılımını sağlayan yöntem ve tekniklere yer verilmiştir. Bunlardan toplu öğretim, yaşamla bağlantı kurma ve iş ilkeleri, 1924 yılında ülkemize gelen John Dewey'in eğitim sistemimiz hakkında sunduğu rapordan etkilenilerek 1926 programında yer almıştır. Bu durumda 2005 ve sonraki programlarda yer alan yaparak yaşayarak öğrenme, öğrencinin öğrenme sürecinde aktif olmas1, konuların bütünleştirilmesi gibi uygulamaların ilk olmadığını, 1926 programında da yer aldığını söylemek mümkündür.

Öğrenme-öğretme süreciyle ilgili olarak 1948 programında, önceki programlardan farklı olarak; bilinenden bilinmeyene ilkesine yer verilmiş, gözlem, gezi, anlatım, uygulama, inceleme, oyun, gösterip yaptırma, deney, grup çalışması gibi yöntem ve teknikler önerilmiştir. 1968 programında, farklı olarak hayatîlik, görünenden görünmeyene ve bireysel farklılıklar ilkesine yer verilmiş, öğretmenin rehber kişi olması ve öğrencinin etkin olması vurgulanmıştır. Bireysel çalışma, küme çalışması ve seviye gruplarının yapılabileceği belirtilmiştir. İlk kez 1968 programında metot ve teknikler bölümüne yer verilmiştir. $\mathrm{Bu}$ yöntem ve teknikler arasında anlatım, soru-cevap, inceleme, gözlem, araştırma, gezi, sergi, iş, gösterme, laboratuvar, deney, proje, problem çözme ve dramatizasyon yer almıştır. 1998 programında, farklı olarak kolaydan zora, basitten karmaşığa, somuttan soyuta ilkeleri yer almıştır. İlk kez 1998 programında derse özel yöntem ve teknikler yer almıştır. En çok önerilen yöntem-teknikler, anlatım, soru-cevap, tartışma, rol yapma, gezi, gösterip yaptırma, inceleme, gözlem, deney, oyun, uygulama, gösteri, pandomimdir.

Öğrenme-öğretme sürecinin, 1998 programına kadar yoğunluklu olarak davranışçı yaklaşımın etkisiyle öğretmen merkezli bir süreç iken, 2005 ve sonrasındaki programlarda yapılandırmacı yaklaşımın etkisiyle öğrencinin bilgiyi kendisinin yapılandırdığı ve öğrenme ortamında öğrencinin aktif olduğu bir sürece doğru evrildiği görülmektedir. 2005/2009 programlarında, öğrenme-öğretme süreci programın en kritik ögesidir. Bu nedenle süreçle ilgili detaylı açıklamalar yapılmıştır. Öğrenci merkezli olan program, etkinliklerle zenginleştirilmiştir. Programda öğretmen rehberdir. Öğrenci bilgiyi kendisi yapılandırmalıdır. Bireysel farklılıklar önemlidir. Farklı öğrenme stillerine ve zekâ alanlarına hitap eden öğrenme ortamları düzenlenmelidir. Aktif öğrenme yöntem ve teknikleri önerilmiştir. Rol oynama, soru-cevap, anlatım, araştırma-bilgi toplama, tartışma en çok önerilenler arasındadır. Çoklu zekâ, altı şapkalı düşünme, beyin firtınası, , vızıltı 66 gibi aktif öğrenmeye dayalı yaklaşım, yöntem ve teknikler ilk kez yer almıştır. Ancak Türky1lmaz'a (2011) göre programda önerilen etkinlikler, bölgesel ve yöresel farkl1lıklar göz önüne alınarak hazırlanmasına rağmen, farklı zekâ alanları ve öğrenme stillerine göre hazırlanmamıştır. Öztürk ve Kalafatçı (2017) tarafından yapılan araştırmada ise öğretmenler, etkinlikleri sayıca yetersiz oldukları, açık ve net olmadıkları, öğrencilerin merakını cezbetme, yaratıcı düşünme ve işbirlikli çalışma gibi becerilerinin geliştirilmesinde yetersiz kaldıkları yönünde eleştirmişlerdir. Ayrıca etkinlikler için verilen ders süresini yetersiz olarak ifade etmişlerdir. Gülener (2010) tarafından yapılan çalışmada ise farklı olarak, 
Hayat Bilgisi öğretim programındaki etkinliklerin, ilgili oldukları temalar ve becerilerle örtüştügü, kazanımlarla ilişkili olduğu ve kazanımları vermeye yönelik hazırlandığı sonucuna ulaşılmıştır.

2005/2009 programlarında. yapılandırıcı yaklaşım esas alındığı belirtilmesine rağmen; 2015, 2017 ve 2018 programlarında, programların dayandırıldığ 1 felsefe ifade edilmezken, programların öğrenci merkezli olduğu belirtilmiştir. Bununla birlikte 2015, 2017 ve 2018 programlarında, programın uygulanmasına ilişkin detaylı açıklamalar yerine birkaç maddelik açıklama yapılmıştır. Etkinlik örnekleri kaldırılmış, okul içi ve dışı uygulamalarla yaşamla bağlantı kurma esas alınmıştır. Öğrencilerin ilgi, istek ve ihtiyaçları dikkate alınarak hazırlanan etkinlikler yoluyla, yaşam becerilerinin geliştirilmesi ve değerlerin kazandırılmasına önem verilmiştir.

Programların ölçme-değerlendirme ögesi ile ilgili olarak; ölçme-değerlendirme boyutunun 1998 programına kadar ihmal edildiği, 1998 ve sonraki programlarda ölçme-değerlendirmeye daha fazla yer verildiği söylenebilir. 1926, 1936 ve 1948 programlarında ölçme ve değerlendirme ögesine yer verilmemiştir. Ancak bu programlarda yer alan gözlem defteri tutma, koleksiyon yapma, yıl sonu yapılan sınıf ve okul sergilerinin öğrencileri değerlendirme amacıyla kullanılan günümüz portfolyo uygulamasıly benzerlik gösterdiği söylenebilir. Çelenk, Tertemiz ve Kalaycı'ya (2000) göre yı1 sonu sergileri, ilkokulun çalışma ilkelerini ve yöntemlerini halka anlatmak, benimsetmek, velilere çocuklarının nasıl çalışıp ilerlediklerini göstermek, öğrenciye bir yıllık işlerinin bilançosunu göstermek amaciyla düzenlenmiştir. 1968 programında Hayat Bilgisi dersine özel ölçme-değerlendirme ögesi bulunmamakla birlikte; ilkokul programında tüm dersler için değerlendirmenin günlük, haftalık, aylık değerlendirme; ünite işlenişi sırasında ara değerlendirme, dönem ve yıl sonu değerlendirmeleri olarak yapılması gerektiği; değerlendirmenin öğretmen katılımı ile yapılabildiği gibi öğrencinin kendini değerlendirmesi, küme ve grup çalışmalarının değerlendirilmesi şeklinde de yapılabileceği belirtilmiştir. 1998 Hayat Bilgisi programında ilk kez derse özel ölçme-değerlendirme ögesi yer almıştır. Programda, ürün odaklı değerlendirme anlayışı hâkimdir. Klasik ölçme ve değerlendirme araçları ile gözlem formunun kullanılabileceği, öğretmenlerin belirtke tablosunu kullanarak ölçme soruları/gözlem formu hazırlayabilecekleri, ölçme araçlarını çeşitlendirebilecekleri belirtilmiştir.

2005 ve sonrasında hazırlanan programların hepsinde, yapılandırmacı felsefenin etkisiyle, ürün ve süreç odaklı değerlendirme anlayışı benimsenmiştir. $\mathrm{Bu}$ programlarda klasik ölçme-değerlendirme araçlarının yanı sıra yapılandırmacı öğrenmeye dayalı alternatif/çoklu ölçme-değerlendirme yaklaşımları kullanılması gerektiği belirtilmiştir. Öz değerlendirme, ürün dosyası, dereceli puanlama anahtarı, proje, performans değerlendirme, tutum ölçekleri bunlardan bazılarıdır. 2017 programında, tanıma, izleme ve ürün odaklı değerlendirme yapılarak, öğrencilerin süreç boyunca izlenmesi, , ögrencilerde anlamlı ve kalıc1 öğrenmenin desteklenmesi ve öğrenme güçlüklerinin giderilmesi amacıyla geri bildirimin sağlanmasına yönelik bir anlayış benimsenmiştir. 2018 programında ise, çok odaklı ölçme-değerlendirme anlayışı esas alınarak, ölçme-değerlendirme sürecinde esneklik ve çeşitlilik anlayışıyla hareket edilmesi gerektiği belirtilmiştir. Gümüş ve Aykaç (2012) tarafından yapılan çalışmada öğretmenler, geleneksel ve alternatif ölçme-değerlendirme araçlarını harmanlayarak kullandıklarını; ancak değerlendirme süreçleri hakkında yeterli hizmet içi eğitim alamamaları nedeniyle, alternatif ölçme-değerlendirme araçlarını uygulama ve değerlendirme açısından bazı sıkıntılar yaşadıklarını belirtmişlerdir. Öztürk ve Kalafatçı (2017) tarafından yapılan çalışmada öğretmenler, 2009 programındaki ölçme-değerlendirme yöntemlerinin açık ve net olmadığı, amaca uygunluk ve süre açısından yetersiz olduğunu, öğrencilerin başarılarının artması için onları yeterince motive etmediğini belirtmişlerdir. Türkyılmaz (2011) öğretmenlerle yaptığı araştırmasında, programının ölçme-değerlendirme ögesinde kullanılan tekniklerin yeterli olmadığı sonucuna ulaşmış ve öğrencilerin tüm becerilerinin değerlendirilemediğini belirtmiştir.

Sonuç olarak, 1926'dan günümüze kadar Hayat Bilgisi öğretim programlarının ögelerinde meydana gelen değişiklikler incelendiğinde, önemli değişiklikler yapıldığı görülmektedir. Yapılan araştırmalar incelendiğinde, özellikle son dönemlerde hazırlanan programların ögeleri ile ilgili farklı sonuçlara ulaşıldığı görülmektedir. Araştırma sonuçlarındaki bu farklılığın, programların uygulama kısmında yer alan öğretmenlerin öğrenci merkezli eğitim hakkında yeterince deneyim sahibi olmamaları ya da programlar hazırlanırken uygulama şartlarının yeterince dikkate alınmaması gibi nedenlerden kaynaklandığı söylenebilir.

\section{1. Öneriler}

$\mathrm{Bu}$ araştırmanın sonuçlarına dayalı olarak geliştirilen öneriler şunlardır:

Hayat Bilgisi dersinin ilk kez yer aldığ 1926 İlkokul programında, öğrenme-öğretme sürecinin öğrenci merkezli olması gerektiğinin belirtildiğini görüyoruz. Bu durumda yapılandırmacı yaklaşımla, 
sanki eğitim dünyamıza yeni girmiş gibi gösterilen bazı değişimlerinin temellerinin, aslında geçmiş programlarda var olduğu söylenebilir. Bu nedenle program geliştirme çalışmaları ile yeni programlar hazırlanırken, geçmişteki olumlu uygulamaları birleştiren, birikimli bir bakış açısına sahip olunması, daha nitelikli ve işlevsel programların hazırlanmasını sağlayabilir.

Programda yer alan kazanımların öğrencilerin gerçek yaşamlarıyla yeterince örtüşmesi, öğrenme ve bilimsel araştırma merakını teşvik edici, yaratıcı ve eleştirel düşünme becerisini geliştirici nitelikte olması sağlanabilir.

Hayat Bilgisi öğretim programlarının içerik ögesi düzenlenirken, evrensel ve ulusal değerler açısından, birinin diğerine baskın gelmediği bir bakış açısı ile içerik ögesi hazırlanabilir.

1926'dan itibaren Hayat Bilgisi öğretim programlarında öğrenci merkezli bir öğretme-öğrenme süreci ve ölçme-değerlendirme ögesi önerilmesine rağmen, uygulamada halen sıkıntılar yaşandığ söylenebilir. Bu nedenle, programların uygulama kısmında yer alan öğretmenlere, hizmet içi eğitim programları düzenlenerek öğrenci merkezli öğrenme-öğretme süreci ve ölçme-değerlendirme etkinlikleri konusunda deneyim sağlanabilir.

Yapılacak olan yeni araştırmalarla, Hayat Bilgisi öğretim programını oluşturan ögelerin, alandaki yeniliklere ve bilimsel gelişmelere bağlı olarak yetersiz kalan kısımları belirlenebilir ve program geliştirme çalışmaları ile daha işlevsel bir program hazırlanabilir. 


\section{KAYNAKLAR}

Alak, G. (2011). Hayat Bilgisi öğretim programı ögelerinin öğretmen görüşlerine göre değerlendirilmesi. Yayımlanmamış yüksek lisans tezi, Atatürk Üniversitesi, Erzurum.

Aslan, E. (2011). Türkiye Cumhuriyeti'nin ilkokullarda izlediği ilköğretim programı: 1924 ilk mektepler müfredat programı. Elementary Education Online, 10(2), 717-734.

Aykaç, N. (2011). Hayat Bilgisi dersi öğretim programında kullanılan yöntem ve tekniklerin öğretmen görüşlerine göre değerlendirilmesi (Sinop ili örneği). Kastamonu Eğitim Dergisi, 1(19), 113-126.

Belet, Ş. D. (1999). İlköğretim kurumlarında uygulanan Hayat Bilgisi programının değerlendirilmesi. Yayımlanmamış yüksek lisans tezi, Anadolu Üniversitesi, Eskişehir.

Bıkmaz, F. (2013a). 1924 ilkmekteplerin müfredat programı. F. D. Gözütok, \& B1kmaz (Ed.), Cumhuriyet'in ilânından 2013'e öğretim programlarının analizi Hayat Bilgisi örneği içinde (s. 33). Ankara: Yargı.

Bıkmaz, F. (2013b). 1926 ilkmektepler müfredat programı (Hayat Bilgisi dersi). F. D. Gözütok, \& F. Bıkmaz (Ed.), Cumhuriyet'in ilânından 2013'e öğretim programlarının analizi Hayat Bilgisi örneği içinde (s. 46). Ankara: Yargi.

Christensen, L. B., Johnson, R. B., \& Turner, L. A. (2015). Araştırma Yöntemleri Desen ve Analiz. (A. Aypay, Çev.). Ankara: Anı.

Çelenk, S., Tertemiz, N., \& Kalaycı, N. (2000). İlköğretim programları ve gelişmeler: Program geliştirme ilke ve teknikleri açısından değerlendirilmesi. Ankara: Nobel.

Demir, M. K. (2016). Hayat Bilgisi öğretim programının değiştirilmesi gerekçelerine dair öğretmen adayı görüşleri. The Journal of Academic Social Science Studies, 47, 157-171.

Gözütok, F. D. (2010). Milli Eğitim, çocuklara ulusal değerleri kazandırmaktan neden vazgeçiyor?. İlköğretim Online, 9(2), 601-629.

Gözütok, F. D. (2013). 2005/2009 ilköğretim programı (Hayat Bilgisi dersi). F. D. Gözütok, \& F. Bıkmaz (Ed.), Cumhuriyet'in ilânından 2013'e öğretim programlarının analizi Hayat Bilgisi örneği içinde (s. 227). Ankara: Yargi.

Gülcan, M., Türkeli, Y., Parabakan, F., Şölen, A., \& Albayrak, F. (2003). Türkiye’de ilköğretim (dünü, bugünü, yarını). İstanbul: Milli Eğitim Basımevi.

Gülener, S. (2010). Hayat Bilgisi öğretim programına ilişkin öğretmen görüşlerinin değerlendirilmesi (Şanlıurfa ili örneği). Yayımlanmamış yüksek lisans tezi, Erzincan Üniversitesi, Erzincan.

Gümüş, M., \& Aykaç, N. (2012). Hayat Bilgisi dersi öğretim programının değerlendirme öğesinin öğretmen görüşleri doğrultusunda değerlendirilmesi. Elektronik Sosyal Bilimler Dergisi, 11 (40), 59-68.

Güven, M. M. (2010). Türkiye’ de ilköğretim Hayat Bilgisi dersi programı değiş̧iklikler, düzenlemeler, güncellemeler. Yayımlanmamış yüksek lisans tezi, Selçuk Üniversitesi, Konya.

Kültür Bakanlığı. (1936). İlkokul programı. İstanbul: Devlet Basımevi.

Maarif Vekâleti. (1930). İlkmektep müfredat programı. İstanbul: Devlet Matbaası.

Milli Eğitim Bakanlığı. (1948). İlkokul programı. İstanbul: Milli Eğitim Basımevi.

Milli Eğitim Bakanlığı. (1969). İlkokul programı. İstanbul: Milli Eğitim Basımevi.

Milli Eğitim Bakanlı̆̆ı. (2009). İlköğretim 1, 2 ve 3.Sınıflar hayat bilgisi dersi öğretim programı ve kılavuzu. 04.12.2016 tarihinde www.meb.gov.tr. adresinden alınmıştır.

Milli Eğitim Bakanlığı. (2015). İlkokul hayat bilgisi dersi (1,2,3.sınıflar) öğretim programı. 14.08.2015 tarihinde www.meb.gov.tr. adresinden alınmıştır.

Milli Eğitim Bakanlığı. (2017). Hayat bilgisi dersi öğretim programı (İlkokul 1,2 ve 3.sınıflar) 05.09.2017 tarihinde www.meb.gov.tr. adresinden alınmıştır.

Milli Eğitim Bakanlığı. (2018). Hayat bilgisi dersi öğretim programı (İlkokul 1,2 ve 3.sınıflar) 29.08.2018 tarihinde www.meb.gov.tr. adresinden alınmıştır.

Ocak, G., \& Beydoğan, H.Ö. (2005). İlköğretim okulları 3. sınıf Hayat Bilgisi dersi içerik standartlarının öğretmen görüşlerine göre bazı değişkenler açısından yeterlilik düzeyi (standart belirleme-Erzurum örneği). Gazi Üniversitesi Kırşehir Eğitim Fakültesi, 6 (1), 109- 135.

Özden, Y. (2006). 2004 Hayat Bilgisi pilot programının, 1998 Hayat Bilgisi programıyla karşılaştırılması. Yayımlanmamış yüksek lisans tezi, Ondokuz Mayıs Üniversitesi, Samsun.

Öztürk, T., \& Kalafatçı, Ö. (2017). Hayat Bilgisi dersi öğretim programının öğretmen görüşlerine göre incelenmesi. Eğitim ve Toplum Araştırmaları Dergisi, 4 (2), 102-123.

Patton, M, Q. (2014). Nitel araştırma ve değerlendirme yöntemleri. (M.Bütün, \& S. B. Demir, Çev.). Ankara: Pegem Akademi. 
Şahin, M. (2009). Cumhuriyetin kuruluşundan günümüze Türkiye'de Hayat Bilgisi dersi programlarının gelişimi. Uluslararası Sosyal Araştırmalar Dergisi, 2 (8), 402-410.

Şahin, M. (2017). Social Studies curricula in Turkey: Historical evolution. European Journal of Education Studies, 3(2), 48-64.

Tay, B., \& Baş, M. (2015). 2009 ve 2015 yılı Hayat Bilgisi dersi öğretim programlarının karşılaştırılması. Bayburt Üniversitesi Eğitim Fakültesi Dergisi, 10 (2), 341-374.

Tay, B., \& Yıldırım, K. (2013). Bilgisayar destekli öğretimin Hayat Bilgisi öğretimi dersinde başarıya etkisi ve yönteme ilişkin öğretmen adaylarının görüşleri. Uşak Üniversitesi Sosyal Bilimler Dergisi, 6(1), 84-110.

Tuncer, Ö. (2009). İlköğretim 3. sınıf Hayat Bilgisi öğretim programının öğretmen görüşlerine göre değerlendirilmesi. Yayımlanmamış yüksek lisans tezi, Adnan Menderes Üniversitesi, Aydın.

Türe, E. (2013). 1936 ilkokul programı (hayat bilgisi dersi). F. D. Gözütok, \& F. B1kmaz (Ed.), Cumhuriyet'in ilânından 2013'e öğretim programlarının analizi Hayat Bilgisi örneği içinde (s. 82). Ankara: Yargı Yayınevi.

Türkyılmaz, A. (2011). İlköğretim Hayat Bilgisi öğretim programının öğretmen görüşlerine dayalı olarak değerlendirilmesi (Balıkesir ili örneği). Yayımlanmamış yüksek lisans tezi, Balıkesir Üniversitesi, Balıkesir.

Uğur, T. (2006). 2005 ilköğretim 1. 2. ve 3. sınıflar Hayat Bilgisi dersi öğretim programına ilişkin öğretmen görüşleri (Uşak ili örneği). Yayımlanmamış yüksek lisans tezi, Afyonkarahisar Kocatepe Üniversitesi, Afyon.

Vural, M. (2003). İlköğretim okulu programı. Erzurum: Yakutiye.

Vural, M. (2005). İlköğretim okulu ders programları ve öğretim kılavuzları 1-5.sınıflar. Erzurum: Yakutiye.

Yıldırım, A., \& Şimşek, H. (2016). Sosyal bilimlerde nitel araştırma yöntemleri (10. Baskı). Ankara: Seçkin. 